Published in final edited form as:

Clin Exp Allergy. 2019 April ; 49(4): 419-429. doi:10.1111/cea.13320.

\title{
Impact of Parental Asthma, Prenatal Maternal Asthma Control and Vitamin D Status on Risk of Asthma and Recurrent Wheeze in 3-Year Old Children
}

\author{
Hooman Mirzakhani, MD, PhD, MMSc ${ }^{1}$, Vincent J. Carey, $\mathrm{PhD}^{1}$, Robert Zeiger, MD, $\mathrm{PhD}^{2}$, \\ Leonard B. Bacharier, MD ${ }^{3}$, George T. O'Connor, MD, MS ${ }^{4}$, Michael X. Schatz, MD, MS ${ }^{5}$, \\ Nancy Laranjo, MS ${ }^{1}$, Scott T. Weiss, MD, MS ${ }^{\# 1,6}$, and Augusto A. Litonjua, MD, MPH ${ }^{\# 7}$ \\ ${ }^{1}$ Channing Division of Network Medicine, Department of Medicine, Brigham and Women's \\ Hospital, Harvard Medical School, Boston, Massachusetts \\ ${ }^{2}$ Department of Allergy and Research and Evaluation, Kaiser Permanente Southern California \\ Region, San Diego and Pasadena, California \\ ${ }^{3}$ Division of Pediatric Allergy, Immunology and Pulmonary Medicine, Department of Pediatrics, \\ Washington University, St. Louis, Missouri \\ ${ }^{4}$ Pulmonary Center, Department of Medicine, Boston Medical Center, Boston University, Boston, \\ Massachusetts \\ ${ }^{5}$ Department of Allergy and Research and Evaluation, Kaiser Permanente Southern California \\ Region, San Diego and Pasadena, California \\ ${ }^{6}$ Partners Center for Personalized Medicine, Partners Health Care, Boston, MA \\ ${ }^{7}$ Division of Pediatric Pulmonary Medicine, Department of Pediatrics, Golisano Children's Hospital \\ at Strong, University of Rochester Medical Center, Rochester, NY \\ \# These authors contributed equally to this work.
}

\section{Abstract}

Corresponding author: Augusto A. Litonjua, MD, MPH, Division of Pulmonary Medicine, Department of Pediatrics, Golisano Children's Hospital at Strong, University of Rochester Medical Center, Office: (585) 275-2464, Fax: (585) 275-706,

Augusto_Litonjua@URMC.Rochester.edu.

Author contributions:

STW and AAL were the principle investigator of VDAART. AAL, GTO, LBB, RZ, MXS, NL, VJC, and STW contributed to the design, coordination, and conduct of the trial. HM, conceived the study design, performed the analysis and wrote the manuscript. STW and AAL also assisted in the design of the study. VJC assisted in the analysis of the data. HM, VJC, STW and AAL contributed to the discussion of the statistical analysis plan and interpretation of study results. All authors contributed to the relevant sections and approved the final manuscript. The corresponding author had full access to all the data and had final responsibility for the decision to submit for publication.

VDAART registration: This study is a secondary analysis of the data from Vitamin D Antenatal Asthma Reduction Trial (VDAART). VDAART is registered on clinicaltrials.gov with identification number NCT00920621.

Ethics Approval: VDAART IRB approval was obtained from each of the three clinical centers and the Data Coordinating Center, i.e. Washington University in St. Louis, Kaiser Health Care San Diego, Boston Medical Center and Brigham and Women's Hospital in Boston.

Conflict of Interests: Authors declare that they have no significant competing financial, professional or personal interests that might have influenced the performance or presentation of the work described in this manuscript. 
Background-While familial clustering of asthma is known, few studies have reported on the relative roles of paternal and maternal asthma, and the role of maternal asthma control in pregnancy on the risk for asthma in the child.

Objective-We aimed to investigate the relative roles of paternal asthma, maternal asthma, and maternal asthma control during pregnancy on the risk of asthma or recurrent wheeze in 3-year old children how prenatal and cord blood vitamin D status might affect this risk.

Methods-Data from 806 women, their partners (biologic fathers of the infant), and their children participated in the Vitamin D Antenatal Asthma Reduction Trail (VDAART, clinicaltrials.gov identification number NCT00920621) were used for this cohort analysis. The parental report of physician-diagnosed asthma or recurrent wheeze in offspring was the main outcome. Weibull regression models for interval-censored event times were used to estimate the main variables of interests and additional covariates on the outcome.

Results-The highest risk was observed among children with both parents being asthmatic relative to non-asthmatic parents ( $\mathrm{aHR}=2.30,95 \% \mathrm{CI}: 1.35-3.84$ ), and less so if only the mother was asthmatic (aHR=1.70, 95\%CI: 1.17-2.40). In the subset of children born to asthmatic mothers, the risk for asthma was higher in those who were born to mothers whose asthma was uncontrolled (aHR=1.60, 95\%CI: 1.02-2.54). Children whose mothers had sufficient vitamin D status (25Hydroxyvitamin D $\geq 30 \mathrm{ng} / \mathrm{mL}$ ) at early and late pregnancy and had cord blood vitamin D sufficiency demonstrated a lower risk of asthma/recurrent wheeze than children who had insufficient vitamin D status at birth (aHR=0.47, 95\%CI: 0.27-0.83).

\section{Keywords}

Child Wheeze; Child Asthma; Cord Blood; Child Sex; Parental Asthma; Prenatal Vitamin D; Prenatal Maternal Asthma Control

\section{Introduction}

In 2015, asthma was reported as the most prevalent chronic respiratory disease worldwide. (1) Data from surveys that use current episodes of wheezing or a physician's diagnosis of asthma for the definition of disease show that asthma affects 5-16\% of people worldwide and continues to grow. A recent study estimated that the prevalence of asthma increased by $12.60 \%$ (9.0-16.40) to 358.20 million individuals (323.10 million to 393.50 million) from 1990 to 2015.(1)

In many children wheezing is transient, however, those who wheeze in the first 3 years of life are found to be at higher risk of asthma at the age of 5 to 7 years.(2-4) Population-based birth cohort studies suggest that the majority of individuals diagnosed with asthma during first two decades of life had recurrent wheezing episodes during early life and the preschool years. $(4,5)$ These observations indicate that early life perturbation of biological developmental processes might either initiate or enhance a pre-clinical stage of asthma years before the physician diagnosis of the disease.(6) Such mechanistic alterations could be more prominent in predisposed persons since genetic and immunological studies point to potentially inherited early life defective responses of lung resident cells, in particular, those associated with the mucosal epithelium that are crucial elements in the pathogenesis of 
asthma.(7-10) Parental history of asthma is the strongest risk factor for asthma in the child, with maternal asthma posing a stronger risk than paternal asthma.(11, 12) Few studies, however, have investigated the joint effect of maternal and paternal asthma,(11, 13) Because the fetus is fully dependent on the mother, lack of maternal asthma control in pregnancy may also play a role $(14,15)$ in the risk of asthma and recurrent wheeze in children.

Epidemiological studies are suggestive of an inverse relationship between vitamin D cord blood levels and wheezing in early life and allergy outcomes.(16-18)

The Vitamin D Antenatal Asthma Reduction Trial (VDAART) was designed to enroll mothers with either a personal history of asthma or allergies or a partner with asthma or allergies, to investigate the effect of vitamin D treatment (4400 vs $400 \mathrm{IU}$ ) during pregnancy initiated at 10-18 weeks of gestation on asthma or recurrent wheeze in the offspring at high risk of asthma. The aims of these secondary analyses were to investigate 1) the role of maternal and paternal asthma on the risk for asthma or recurrent wheeze in the children, 2) whether the lack of maternal asthma control during pregnancy increases the risk of asthma or recurrent wheeze, and 3) whether prenatal (early and late pregnancy) and cord blood vitamin D sufficiency (25-hydroxyvitamin D [25OHD] $\geq 30 \mathrm{ng} / \mathrm{mL}$ ) decreases the risk of asthma/recurrent wheeze independent of parental asthma status. Since wheezing illnesses are more common in boys during childhood, we additionally examined whether child sex affected the risk conferred by parental asthma.

\section{Methods}

\section{VDAART Design, Participants and Oversight}

VDAART is a randomized, double-blind, placebo-controlled clinical trial of vitamin D supplementation (4000 International Units Vitamin D plus a multivitamin with 400 IU Vitamin D daily) versus placebo (placebo pill plus a multivitamin with 400 IU vitamin D daily) in pregnant women to prevent asthma and recurrent wheeze in their children. In this study, we included pregnant women who had children who contributed any information after birth, up to the age of 3 years (Supplement Figure S1-study flow diagram). Pregnant women were recruited from 3 clinical sites across the United States-Boston Medical Center, Boston, Massachusetts; Washington University at St. Louis, St. Louis, Missouri; and Kaiser Permanente Southern California Region, San Diego. The data coordinating center was based in the Channing Division of Network Medicine, Brigham and Women's Hospital, Boston, Massachusetts. The study protocol was approved by the institutional review boards at each participating institution and at the Brigham and Women's Hospital and registered with clinicaltrials.gov (NCT00920621). Eligible participants were women between the ages of 18 and 39 years with the estimated gestational ages of 10 and 18 weeks, non-smoker, a history of physician-diagnosed asthma or atopy, or a partner (biologic father of the child) with a history of physician-diagnosed asthma or atopy. Eligible participants per VDAART protocol (Supplement File 1) were screened and enrolled between October 2009 and July 2011. All women provided written informed consent. The data safety monitoring board convened by the National Heart Lung, and Blood Institute met every six months to review recruitment, adherence, adverse events, data quality, and protocol changes. Details of the trial design, the protocol, and primary outcome (asthma and recurrent wheeze by age of 3 years), as well as 
further information on the screening, random allocation and blinding process, compliance assessment, and trial monitoring, have been published.(19, 20)

\section{Primary Outcome: Offspring Asthma or Recurrent Wheeze}

We used the same primary outcome of the VDAART study for this secondary cohort analysis as in the initial report. The primary outcome was the first occurrence of infants' asthma or recurrent wheeze in the first 3 years of life.(19) The child asthma status was determined by a parental report of physician-diagnosis of asthma. Recurrent wheeze was defined by the occurrence of at least one of the following 5 conditions: (1) parental report of wheeze prior to the second birthday followed by at least one report of wheeze after child's second birthday; (2) parental report of wheeze prior to the second birthday followed by report of child's use of asthma controller medication (defined as report of use of steroid inhalers or nebulizers, leukotriene modifiers, or steroid pills or liquids) after the second birthday; (3) two or more distinct parental reports of wheeze after the second birthday; (4) at least one parental report of wheeze and use of asthma controller medications at distinct visits, both subsequent to the second birthday; or (5) two distinct reports of use of asthma controller medications after the second birthday.

\section{Assessment of Main and Additional Study Variables}

The main risk variables of interest included 1) a four-level ordered variable defined for each parent with values both parents without asthma, asthmatic father but non-asthmatic mother, asthmatic mother but non-asthmatic father, and both parents with asthma; 2) a two-level ordered variable defined for each asthmatic mother with values controlled or uncontrolled asthma; and 3) a three level ordered variable defined for each infant with values insufficient status in cord blood (regardless of prenatal levels in the mother), sufficient status in cord blood with at least 1 insufficient status in maternal prenatal blood, and sufficient status in cord blood and sufficient status at both prenatal time points. The maternal samples were measured in blood samples collected at 10-18 weeks and 32-38 weeks of gestation. For the joint effect of prenatal and cord blood vitamin D levels, 25OHD sufficiency status was determined according to the levels cut-off $30 \mathrm{ng} / \mathrm{mL}$ ( $230 \mathrm{ng} / \mathrm{mL}$ vs $<30 \mathrm{ng} / \mathrm{mL}$ ).(21)

Completed questionnaires at enrollment and monthly maternal health questionnaires thereafter provided the information on absence or presence of parental asthma (maternal or paternal) and monitored maternal asthma control status throughout the study until delivery. Either parent was considered to have asthma if the mother reported physician-diagnosed asthma at any time in her or her partner's life at the first appointment questionnaire. Thereafter, the monthly questionnaires prospectively collected information characterizing maternal asthma control status during pregnancy. The Asthma Control Test (ACT), a 5-item questionnaire included in the monthly questionnaires, was used to assess a multidimensional perspective of asthma control on the basis of activity limitation, frequency of shortness of breath due to asthma, nighttime symptoms, use of rescue medication, and self-perception of asthma control over a period of 4 weeks.(22-24) An ACT score of 16 or less was considered as the cutoff for discrimination of uncontrolled asthma from controlled asthma during pregnancy. $(22,24)$ 


\section{Blood Samples and Measurement of 250HD}

Cord blood vitamin D levels and sufficiency status (25OHD $\geq 30 \mathrm{ng} / \mathrm{mL}$ ) were also considered as main variables of interest affecting the risk of offspring asthma of recurrent wheeze by age of 3 years.(25) Plasma vitamin D levels were determined in a blinded fashion from umbilical cord blood plasma collected at birth as predefined in the VDAART protocol. $(19,20)$ Maternal plasma vitamin D levels at enrollment (10-18 weeks) and third trimester (32-38 weeks) were also measured. Measurements of 25OHD were based on liquid chromatography-tandem mass spectrometry (LC-MS/MS) conducted at the Department of Laboratory Medicine and Pathology, Mayo Clinic, Rochester, MN (ThermoFisher Scientific, Franklin, Massachusetts 02038 and Applied Biosystems-MDS Sciex, Foster City, CA 94404). Inter-assay coefficient variations (CV) were all $\leq 6.8 \%$ at various concentrations. Total $25 \mathrm{OHD}$ values including $25(\mathrm{OH}) \mathrm{D}_{2}$ and $25(\mathrm{OH}) \mathrm{D}_{3}$ measured by the above method, were used for the analyses reported here.

\section{Additional Variables}

A priori covariates known or reported to be risk factors for offspring asthma/recurrent wheeze and potential confounders of the measure of association for the main variables of interest with the outcome were extracted from the study questionnaires and data records. $(26,27)$ These maternal variables included: number of prior pregnancies (first or more pregnancy including the current one), maternal age, gestational age at delivery ( 237 weeks vs <37 weeks), race (African American, White, and other), treatment arm of the trial (placebo vs. vitamin D supplementation), body mass index (BMI) at first appointment, clinical center, marital status, and educational status.

\section{Statistical Analysis}

Study group subjects' characteristics (maternal asthmatics and non-asthmatics) were compared using a t-test, Chi-square or Fisher's exact test. To make full use of all available observation time, we used interval-censored event-time analysis to test for the categorical variables of interest on the first occurrence of the primary outcome i.e. asthma diagnosis or recurrent wheeze. We examined the trend of outcome proportions across the risk variables of interest. Furthermore, distributions of outcome-free time of the offspring during first 3 years of life were compared across variables of interest by log-rank trend test, and the KaplanMeier method was used to depict survival curves. Weibull univariable regression models for interval-censored event times were used to estimate the adjusted effects of and other covariates on the outcome.(28) Each of 3 main variables of interest was examined in a separate model and results were compared. Univariable analyses were used to reduce the number of potential confounders. Any potential confounder that had at least a modest $(P<0.20)$ relation with both the outcome variable and the predictor of interest or caused more than $10 \%$ change in baseline coefficient of the predictor of interest in the bivariable analysis was included in later multivariable models. Thereafter, stepwise multivariable Weibull regression models incorporating covariates were used to assess the effects of the main variables of interest. Crude and adjusted hazard ratios (HR and aHR) were calculated with 95\% confidence intervals (CI) and corresponding P values were calculated with the use of the Weibull model. R version 3.4 was used for all analyses (R Foundation for Statistical 
Computing; packages interval, survival, SurvRegCensCov, ggplot2). All tests were 2-sided, and the significance level was pre-specified at $P<0.05$.

\section{Results}

\section{Study groups}

Out of 816 mothers, data on 806 mothers and their children were available for analysis (Figure S1). There were 322 asthmatic mothers and 484 non-asthmatic mothers. Of 484 nonasthmatic mothers, 358 had atopy and the rest had a partner with asthma or atopy. The baseline characteristics of the study groups (maternal asthma vs no maternal asthma) were compared in Table 1. Among those, maternal BMI $\geq 25$ at first appointment was slightly less prevalent among non-asthmatics compared with asthmatics (278/422[57.43\%] and 98/322[65.60\%], respectively, Chi-square $\mathrm{P}=0.044$ ), and higher proportion of partners with a history of asthma among non-asthmatic mothers (57/322[17.70\%] and 132/489[27.27\%] among asthmatics and non-asthmatics, respectively; Chi-square $\mathrm{P}=0.004)$. The incidence of lower respiratory infections (LRTI, at least one occasion) among children born to asthmatic and non-asthmatic mothers was not different $(\mathrm{P}=0.16$, Table 1$)$, however, there was a higher incidence of LRTI (at least one occasion) among children with asthma or recurrent wheeze as compared with those without asthma or recurrent wheeze ( $R=2.8,95 \%$ CI: 2.22-3.48). Maternal atopy history was not different between study groups, i.e. pregnant women with and without asthma $(\mathrm{P}=0.41)$. Furthermore, mothers' report of breast feeding at age of 3 years did not show a difference between those with and without asthma $(\mathrm{P}=0.7$, Table 1).

218 children had asthma/recurrent wheeze by age of 3 years (125 with asthma diagnosis, of whom, $76.8 \%$ also had recurrent wheeze). In asthmatic and non-asthmatic mothers, the incidence of childhood asthma/recurrent wheeze was $115(115 / 322[35.71 \%])$ and 103 (103/484[21.28\%]), respectively. The trend toward higher incidence of asthma/recurrent wheeze during first three years of the offspring's life in asthmatic mothers (regardless of control status) compared with non-asthmatic mothers was further demonstrated in survival (Kaplan Meier) curves in Figure 1A - crude risk (hazard ratio-HR) estimate of 1.88 (95\% CI: $1.44-2.45, \mathrm{P}<0.001)$.

\section{Effect of parental asthma and maternal asthma control status on offspring asthma/ recurrent wheeze}

We examined the effects of categories of parental asthma on the risk of childhood asthma/ recurrent wheeze by age 3 years. The highest risk was observed among children with both parents being asthmatic relative to non-asthmatic parents (aHR=2.30, 95\%CI: 1.35-3.84; Table 2). This risk was relatively lower if only the mother was asthmatic (aHR=1.70, 95\% CI: 1.17-2.40).

In the subset of children born to asthmatic mothers $(\mathrm{N}=322)$, we then analyzed the effect of maternal asthma control in pregnancy. Children born to asthmatic mothers with lack of asthma control (at least with one uncontrolled month) during their pregnancy demonstrated higher risk of asthma/recurrent wheeze as compared with children born to asthmatic mothers with controlled asthma ( $\mathrm{aHR}=1.60,95 \% \mathrm{CI}: 1.02-2.54 ; \mathrm{P}=0.04)$. We then performed 
additional analyses including all mothers $(\mathrm{N}=806)$ to examine if the maternal asthma effect observed initially was being driven by lack of asthma control in pregnancy. To this end, we defined a three-level ordered variable for each mother with values non-asthmatics, asthmatic with controlled asthma, asthmatic with at least one month of uncontrolled asthma. Compared with children born to mothers without asthma, the risk in children born to mothers whose asthma was controlled during pregnancy was still elevated ( $\mathrm{aHR}=1.70$, 95\%CI: 1.17-2.40). This risk was higher among children born to asthmatic mothers who had at least 1 month of uncontrolled asthma during pregnancy $(\mathrm{aHR}=2.40,95 \% \mathrm{CI}$ : $1.50-3.50$, Table 2).

\section{Effect of prenatal and cord blood vitamin D sufficiency on offspring asthma or recurrent wheeze}

Cord blood 25OHD was lower among infants who had asthma/recurrent wheeze by the age of 3 years compared with those who did not have asthma/recurrent wheeze (mean difference of $5.43 \mathrm{ng} / \mathrm{mL}, 95 \% \mathrm{CI}$ : 2.20-8.60; $\mathrm{P}=0.001$ ). Accordingly, cord blood 25OHD levels at delivery, independent of the effect of maternal asthma, was a predictor of asthma and recurrent wheeze such that a 10 -unit increase in cord blood $250 H D$ resulted in a $13 \%$ reduction of child asthma/recurrent wheeze during the first 3 years of life (aHR=0.87, 95\%CI: 0.79-0.97; P=0.01). Sufficient cord blood vitamin D at delivery ( $\geq 30 \mathrm{ng} / \mathrm{mL}$ ), regardless of maternal plasma vitamin D sufficiency status during pregnancy, resulted in a reduced risk of child asthma/recurrent wheeze by $34 \%$ compared with children who had insufficient vitamin D status $(<30 \mathrm{ng} / \mathrm{mL})$ at birth $(\mathrm{aHR}=0.66,95 \% \mathrm{CI}: 0.47-0.90 ; \mathrm{P}=0.002$, Table 2).

Plasma levels of cord blood 25OHD were correlated with maternal plasma 25OHD levels at $32-38$ and $10-18$ weeks of gestation $(0.73$ and 0.39 , respectively; $\mathrm{P}<0.001)$. The incidence of asthma/recurrent wheeze was 32.17(74/230), 23.51(67/285) and 15.84(16/101) among children with cord blood vitamin D insufficiency, cord blood vitamin D sufficiency not preceded by prenatal sufficiency status at both enrollment and third trimester, and cord blood vitamin D sufficiency preceded by prenatal sufficiency status at both enrollment and third trimester, respectively. The incidence demonstrated a reduction of child asthma/recurrent wheeze across the prenatal and cord blood vitamin D sufficiency categories and indicated a difference in hazard rates across ordered vitamin $\mathrm{D}$ categories ( $\mathrm{P}$ for trend $<0.001$, Figure 1B). In multivariable models including parental asthma status and maternal asthma control status as main variables, the trend in risk estimates remained significant across categories of vitamin D sufficiency status (Table 3).

\section{Child sex}

Child's sex did not significantly affect the prior estimated HRs for the association of parental asthma status nor maternal asthma control with asthma/recurrent wheeze in children. Male offspring had independent increased risks for asthma/recurrent wheeze compared with female offspring in these adjusted models (Table 2). 


\section{Discussion}

We have confirmed previously reported findings that maternal asthma is a risk factor for childhood asthma/wheeze by 3 years of age. While paternal asthma did not confer independent risk for asthma/recurrent wheeze in the children, having both parents with asthma conferred higher risk than maternal asthma alone. We then demonstrated that lack of maternal asthma control during pregnancy increased the risk of asthma/recurrent wheeze in children. We also found that having prenatal and cord blood 25OHD sufficient status ( 230 $\mathrm{ng} / \mathrm{mL}$ ) was independently associated with reduced risk of asthma/recurrent wheeze by age of 3 years. Offspring sex did not alter these risk estimates, but boys had a higher risk for asthma/recurrent wheeze than girls.

Our results corroborate the previous studies that maternal asthma is a strong risk factor for early childhood asthma and wheeze (12) and that having both parents with asthma increased the risk further. Few studies investigated the joint effect of parental asthma on risk of childhood asthma. While maternal asthma is an established risk factor, few studies have assessed the additive effects of maternal asthma activity or lack of asthma control during pregnancy.(14, 15) As such we demonstrated that a lack of maternal asthma control during pregnancy confers a higher risk of offspring asthma/recurrent wheeze as opposed to controlled status throughout pregnancy. The estimated risks in our study are consistent with the results from a recent study in a large Danish cohort of asthmatic and non-asthmatic mothers and their children by Liu et al. that showed that compared with controlled asthma or non-asthmatics, uncontrolled asthma during pregnancy was associated with higher risk of early-onset persistent and transient asthma.(15) In a recent work, we demonstrated that asthmatic mothers with lack of asthma control at 10-18 weeks had a higher risk of experiencing additional episodes of uncontrolled asthma later during their pregnancy.(29) These findings stress the importance of optimal asthma control throughout pregnancy for both mothers and their newborns. The higher risk of asthma and recurrent wheeze among children of asthmatic mothers with controlled asthma during pregnancy compared with nonasthmatic mothers is possible evidence of a genetic component for susceptibility to asthma. (30) This genetic susceptibility has been noted and suggested to follow non-monogenic patterns of inheritance.(31-33) An alternative explanation is that mothers and babies usually share very similar environments in the first few years of life.(11)

There is evidence that the predisposition to developing asthma is established in utero and in addition to genetic susceptibility, maternal environmental exposure could influence early life airway hyper-responsiveness and risk of asthma in early and later in life.(34-36) The greater influence of uncontrolled compared with controlled asthma on the development of offspring asthma/recurrent wheeze in our study further supports the role of prenatal environmental risk factors in asthma development in early life. However, the mechanism involved in how a lack of maternal asthma control exerts its intrauterine influences and a subsequent increase in the risk of children's early life asthma risk is unknown. Such an effect could be partly a result of an interplay between genetic factors associated with susceptibility to asthma and those associated with or induced perturbations by uncontrolled asthma during pregnancy. $(6,37)$ 
In our VDAART main results, vitamin D supplementation of 4400 vs. 400 IU initiated at 10-18 weeks of gestation resulted in a trend toward reduction of asthma/recurrent wheeze in the first 3 years of life using an intent to treat analysis $(P=0.051)$.(19) We have subsequently demonstrated that this effect is dependent on initial maternal 25OHD.(38) Here, we demonstrated that cord blood 25OHD sufficiency at delivery reduced asthma/recurrent wheeze incidence by 33\% during first 3 years of life, independent of maternal asthma status. There was a further reduction of the risk (up to $50 \%$, Table 3 ) by maintaining maternal serum 25OHD sufficiency throughout pregnancy. This observation highlights the need to correct maternal vitamin D insufficiency at an early stage of pregnancy and monitor and maintain sufficiency throughout pregnancy. Vitamin D has been implicated in the programming of the immune system, induction of T-regulatory cells at maternal-fetal interface, and fetal development that can influence asthma-related risk factors and outcomes in later life.(39) Furthermore, an effect of maternal vitamin D intake during pregnancy on gene expressions in cord blood has been shown. $(40,41)$ In addition, some studies implicate variants of vitamin $\mathrm{D}$ receptor genes $(V D R)$ interaction with functional variants of genes (e.g. IL10) involved in asthma and atopy, with a potentially protective role.(42) These reports require further investigation.

There are limitations to our study. The VDAART cohort is a population sample of nonsmoking pregnant women with high risk of atopy in their children. This fact might limit the generalizability of the risk estimates. Furthermore, lack of data on pre-pregnancy asthma severity status and a low frequency of uncontrolled asthma among pregnant asthmatic women in our cohort limited our capability to thoroughly investigate domains of asthma control and a dose response effect of uncontrolled asthma among pregnant women with asthma.

In conclusion, we have confirmed previously reported studies that maternal asthma is a key risk factor for asthma/recurrent wheeze in early childhood and demonstrated the additive effect of paternal asthma in augmentation of such an effect. We have also demonstrated that a lack of asthma control during pregnancy increases the risk of offspring asthma/recurrent wheeze in early life. Additionally, vitamin D sufficiency throughout pregnancy confers protection against the development of offspring asthma/recurrent wheeze independently of maternal asthma. These findings suggest that careful attention to maternal asthma control, monitoring vitamin D status and correcting insufficiency at early pregnancy and maintaining the sufficiency status throughout pregnancy have potential preventive roles in offspring asthma/recurrent wheeze. Longer follow-up of the children and additional prospective birth cohort studies are required to confirm our findings. These studies should also investigate potential mechanisms underlying the association between uncontrolled asthma in pregnancy and offspring asthma/recurrent wheeze risk.

\section{Supplementary Material}

Refer to Web version on PubMed Central for supplementary material. 


\section{Acknowledgments:}

The authors thank the women and their children who participated in this trial and all the study staff for their contributions to this research.

Funding: VDAART was supported by U01HL091528 and R01HL091528 from the National Heart, Lung, and Blood Institute (NHLBI). HM was supported by T32-HL00742707, L30-HL129467-01 and 2L30 HL129467-02A1 from NHLBI. VJC supported in part by U41 HG004059 from the National Human Genome Research Institute.

\section{Reference:}

1. Collaborators GBDCRD. Global, regional, and national deaths, prevalence, disability-adjusted life years, and years lived with disability for chronic obstructive pulmonary disease and asthma, 19902015: a systematic analysis for the Global Burden of Disease Study 2015. Lancet Respir Med. 2017;5(9):691-706. [PubMed: 28822787]

2. Martinez FD, Wright AL, Taussig LM, Holberg CJ, Halonen M, Morgan WJ. Asthma and wheezing in the first six years of life. The Group Health Medical Associates. N Engl J Med. 1995;332(3):1338. [PubMed: 7800004]

3. Stern DA, Morgan WJ, Halonen M, Wright AL, Martinez FD. Wheezing and bronchial hyperresponsiveness in early childhood as predictors of newly diagnosed asthma in early adulthood: a longitudinal birth-cohort study. Lancet. 2008;372(9643):1058-64. [PubMed: 18805334]

4. Morgan WJ, Stern DA, Sherrill DL, Guerra S, Holberg CJ, Guilbert TW, et al. Outcome of asthma and wheezing in the first 6 years of life: follow-up through adolescence. Am J Respir Crit Care Med. 2005;172(10):1253-8. [PubMed: 16109980]

5. Strachan D, Gerritsen J. Long-term outcome of early childhood wheezing: population data. Eur Respir J Suppl. 1996;21:42s-7s. [PubMed: 8962617]

6. Clifton VL, Davies M, Moore V, Wright IM, Ali Z, Hodyl NA. Developmental perturbation induced by maternal asthma during pregnancy: the short- and long-term impacts on offspring. J Pregnancy. 2012;2012:741613. [PubMed: 22830026]

7. Martinez FD, Vercelli D. Asthma. Lancet. 2013;382(9901):1360-72. [PubMed: 24041942]

8. Stern DA, Guerra S, Halonen M, Wright AL, Martinez FD. Low IFN-gamma production in the first year of life as a predictor of wheeze during childhood. J Allergy Clin Immunol. 2007;120(4):83541. [PubMed: 17689598]

9. Larsen JM, Brix S, Thysen AH, Birch S, Rasmussen MA, Bisgaard H. Children with asthma by school age display aberrant immune responses to pathogenic airway bacteria as infants. J Allergy Clin Immunol. 2014;133(4):1008-13. [PubMed: 24612682]

10. Baraldo S, Contoli M, Bonato M, Snijders D, Biondini D, Bazzan E, et al. Deficient Immune Response to Viral Infections in Children Predicts Later Asthma Persistence. Am J Respir Crit Care Med. 2018;197(5):673-5. [PubMed: 28862881]

11. Litonjua AA, Carey VJ, Burge HA, Weiss ST, Gold DR. Parental history and the risk for childhood asthma. Does mother confer more risk than father? Am J Respir Crit Care Med. 1998;158(1):17681. [PubMed: 9655726]

12. Lim RH, Kobzik L, Dahl M. Risk for asthma in offspring of asthmatic mothers versus fathers: a meta-analysis. PLoS One. 2010;5(4):e10134. [PubMed: 20405032]

13. Raby BA, Van Steen K, Celedon JC, Litonjua AA, Lange C, Weiss ST, et al. Paternal history of asthma and airway responsiveness in children with asthma. Am J Respir Crit Care Med. 2005;172(5):552-8. [PubMed: 15937295]

14. Martel MJ, Rey E, Beauchesne MF, Malo JL, Perreault S, Forget A, et al. Control and severity of asthma during pregnancy are associated with asthma incidence in offspring: two-stage case-control study. Eur Respir J. 2009;34(3):579-87. [PubMed: 19541714]

15. Liu X, Agerbo E, Schlunssen V, Wright RJ, Li J, Munk-Olsen T. Maternal asthma severity and control during pregnancy and risk of offspring asthma. J Allergy Clin Immunol. 2018;141(3):88692 e3. [PubMed: 28712803] 
16. Wegienka G, Havstad S, Zoratti EM, Kim H, Ownby DR, Johnson CC. Association between vitamin D levels and allergy-related outcomes vary by race and other factors. J Allergy Clin Immunol. 2015;136(5):1309-14 e1-4. [PubMed: 26078105]

17. Baiz N, Dargent-Molina P, Wark JD, Souberbielle JC, Annesi-Maesano I, Group EM-CCS. Cord serum 25-hydroxyvitamin D and risk of early childhood transient wheezing and atopic dermatitis. J Allergy Clin Immunol. 2014;133(1):147-53. [PubMed: 23810764]

18. Camargo CA,, Jr., Ingham T, Wickens K, Thadhani R, Silvers KM, Epton MJ, et al. Cord-blood 25-hydroxyvitamin D levels and risk of respiratory infection, wheezing, and asthma. Pediatrics. 2011;127(1):e180-7. [PubMed: 21187313]

19. Litonjua AA, Carey VJ, Laranjo N, Harshfield BJ, McElrath TF, O'Connor GT, et al. Effect of Prenatal Supplementation With Vitamin D on Asthma or Recurrent Wheezing in Offspring by Age 3 Years: The VDAART Randomized Clinical Trial. JAMA. 2016;315(4):362-70. [PubMed: 26813209]

20. Litonjua AA, Lange NE, Carey VJ, Brown S, Laranjo N, Harshfield BJ, et al. The Vitamin D Antenatal Asthma Reduction Trial (VDAART): rationale, design, and methods of a randomized, controlled trial of vitamin D supplementation in pregnancy for the primary prevention of asthma and allergies in children. Contemp Clin Trials. 2014;38(1):37-50. [PubMed: 24614387]

21. Holick MF, Binkley NC, Bischoff-Ferrari HA, Gordon CM, Hanley DA, Heaney RP, et al. Evaluation, treatment, and prevention of vitamin D deficiency: an Endocrine Society clinical practice guideline. J Clin Endocrinol Metab. 2011;96(7):1911-30. [PubMed: 21646368]

22. de Araujo GV, Leite DF, Rizzo JA, Sarinho ES. Asthma in pregnancy: association between the Asthma Control Test and the Global Initiative for Asthma classification and comparisons with spirometry. Eur J Obstet Gynecol Reprod Biol. 2016;203:25-9. [PubMed: 27236601]

23. Mirzakhani H, Carey VJ, McElrath TF, Laranjo N, O'Connor G, Iverson RE, et al. The Association of Maternal Asthma and Early Pregnancy Vitamin D with Risk of Preeclampsia: An Observation From Vitamin D Antenatal Asthma Reduction Trial (VDAART). J Allergy Clin Immunol Pract. 2018;6(2):600-8 e2. [PubMed: 28923490]

24. Monteiro de Aguiar M, Rizzo JA, de Melo Junior EF, Pires Lins ESLME, Cavalcanti Sarinho ES Validation of the Asthma Control Test in pregnant asthmatic women. Respir Med. 2014;108(11): 1589-93. [PubMed: 25294692]

25. Thacher TD, Clarke BL. Vitamin D insufficiency. Mayo Clin Proc. 2011;86(1):50-60. [PubMed: 21193656]

26. Gong T, Lundholm C, Rejno G, Mood C, Langstrom N, Almqvist C. Parental socioeconomic status, childhood asthma and medication use--a population-based study. PLoS One. 2014;9(9):e106579. [PubMed: 25188036]

27. Basagana X, Sunyer J, Kogevinas M, Zock JP, Duran-Tauleria E, Jarvis D, et al. Socioeconomic status and asthma prevalence in young adults: the European Community Respiratory Health Survey. Am J Epidemiol. 2004;160(2):178-88. [PubMed: 15234940]

28. Kleinbaum DG, Klein M. Survival Analysis: A Self-learning Text. 3 ed. New York, NY: Springer 2012.

29. Mirzakhani H, O’Connor G, Bacharier LB, Zeiger RS, Schatz MX, Weiss ST, et al. Asthma control status in pregnancy, body mass index, and maternal vitamin D levels. J Allergy Clin Immunol. 2017;140(5):1453-6 e7. [PubMed: 28606587]

30. Duffy DL, Martin NG, Battistutta D, Hopper JL, Mathews JD. Genetics of asthma and hay fever in Australian twins. Am Rev Respir Dis. 1990;142(6 Pt 1):1351-8. [PubMed: 2252253]

31. Bleecker ER, Postma DS, Meyers DA. Evidence for multiple genetic susceptibility loci for asthma. Am J Respir Crit Care Med. 1997;156(4 Pt 2):S113-6. [PubMed: 9351590]

32. Marsh DG, Meyers DA. A major gene for allergy--fact or fancy? Nat Genet. 1992;2(4):252-4. [PubMed: 1303274]

33. Sandford A, Weir T, Pare P. The genetics of asthma. Am J Respir Crit Care Med. 1996;153(6 Pt 1): 1749-65. [PubMed: 8665031]

34. Flanigan C, Sheikh A, Nwaru BI. Prenatal maternal psychosocial stress and risk of asthma and allergy in their offspring: protocol for a systematic review and meta-analysis. NPJ Prim Care Respir Med. 2016;26:16021. [PubMed: 27196620] 
35. Bracken MB, Belanger K, Cookson WO, Triche E, Christiani DC, Leaderer BP. Genetic and perinatal risk factors for asthma onset and severity: a review and theoretical analysis. Epidemiol Rev. 2002;24(2):176-89. [PubMed: 12762091]

36. Caliskan M, Bochkov YA, Kreiner-Moller E, Bonnelykke K, Stein MM, Du G, et al. Rhinovirus wheezing illness and genetic risk of childhood-onset asthma. N Engl J Med. 2013;368(15):1398407. [PubMed: 23534543]

37. Osei-Kumah A, Smith R, Jurisica I, Caniggia I, Clifton VL. Sex-specific differences in placental global gene expression in pregnancies complicated by asthma. Placenta. 2011;32(8):570-8. [PubMed: 21641640]

38. Wolsk HM, Chawes BL, Litonjua AA, Hollis BW, Waage J, Stokholm J, et al. Prenatal vitamin D supplementation reduces risk of asthma/recurrent wheeze in early childhood: A combined analysis of two randomized controlled trials. PLoS One. 2017;12(10):e0186657. [PubMed: 29077711]

39. Mirzakhani H, Al-Garawi A, Weiss ST, Litonjua AA. Vitamin D and the development of allergic disease: how important is it? Clin Exp Allergy. 2015;45(1):114-25. [PubMed: 25307157]

40. Rochat MK, Ege MJ, Plabst D, Steinle J, Bitter S, Braun-Fahrlander C, et al. Maternal vitamin D intake during pregnancy increases gene expression of ILT3 and ILT4 in cord blood. Clin Exp Allergy. 2010;40(5):786-94. [PubMed: 20030662]

41. Hornsby E, Pfeffer PE, Laranjo N, Cruikshank W, Tuzova M, Litonjua AA, et al. Vitamin D supplementation during pregnancy: Effect on the neonatal immune system in a randomized controlled trial. J Allergy Clin Immunol. 2018;141(1):269-78 e1. [PubMed: 28552588]

42. Bosse Y, Lemire M, Poon AH, Daley D, He JQ, Sandford A, et al. Asthma and genes encoding components of the vitamin D pathway. Respir Res. 2009;10:98. [PubMed: 19852851] 


\section{Conclusion and Clinical Relevance}

Careful attention to maternal asthma control, monitoring vitamin D status and correcting insufficiency at early pregnancy and maintaining the sufficiency status throughout pregnancy have potential preventive roles in offspring asthma or recurrent wheeze. 


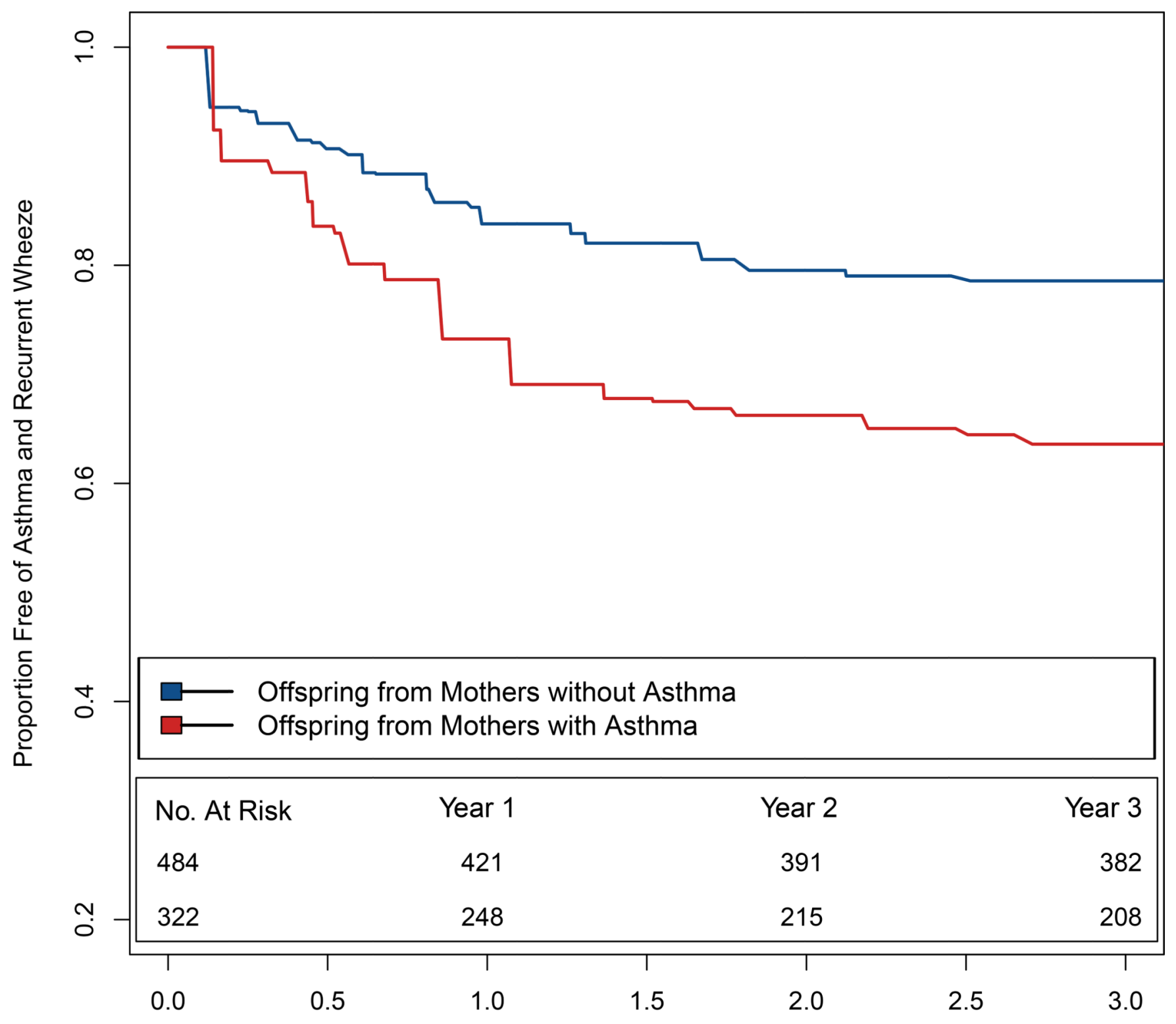

Age in Years

Figure 1A.

Kaplan-Meier survival estimates demonstrating the proportion of children free of asthma/ recurrent wheeze by maternal asthma status. Estimates were obtained from nonparametric maximum likelihood estimation with interval-censored response times $(\mathrm{P}<0.001)$. The hazard ratio (HR) for the time to the first event of asthma or recurrent wheeze obtained using Weibull regression model was 1.88 (95\%CI: 1.44-2.45, $\mathrm{P}<0.001$ ). 


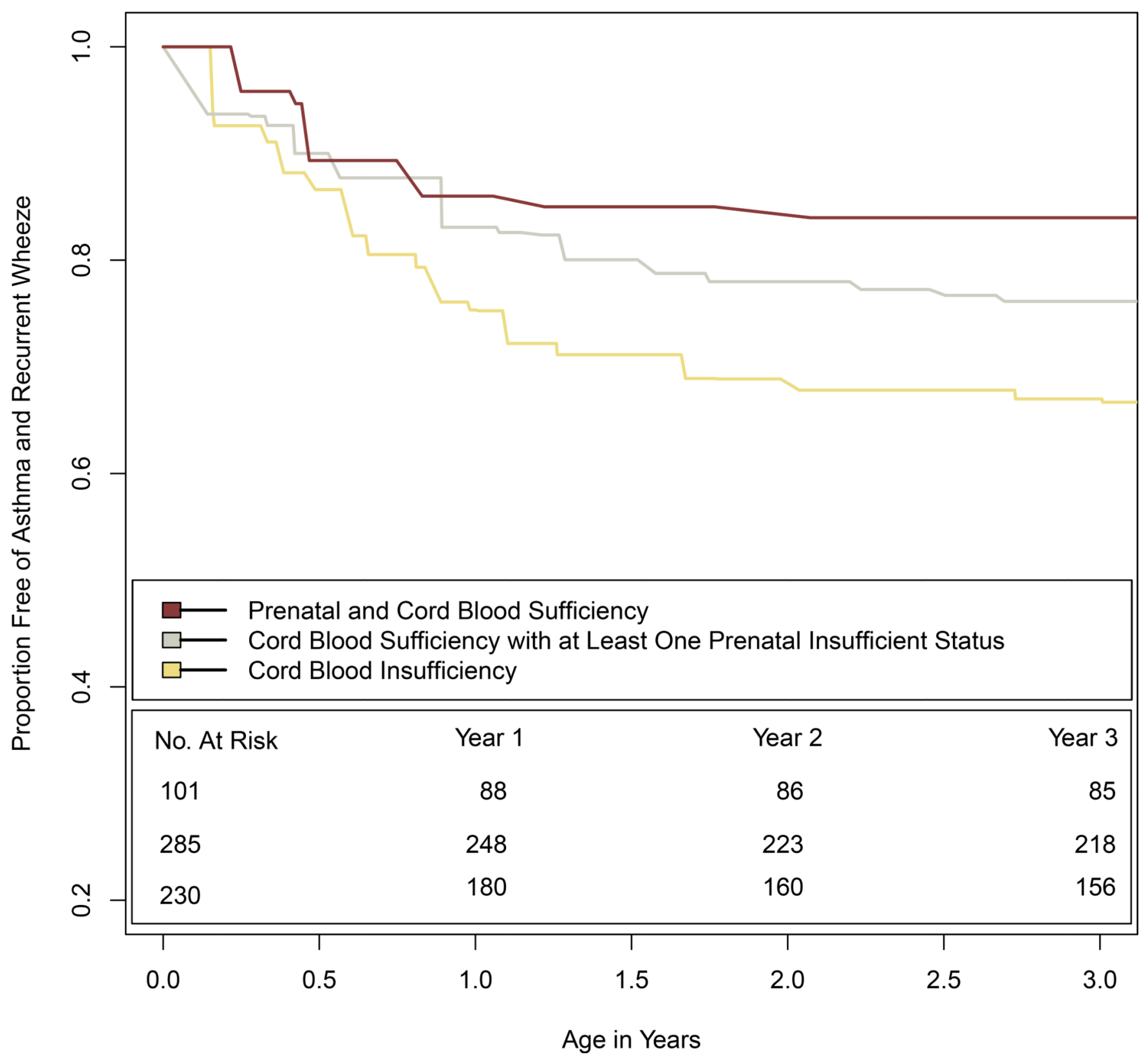

Figure 1B.

Kaplan-Meier survival estimates demonstrating the proportion of children free of asthma/ recurrent wheeze by prenatal and cord blood vitamin $\mathrm{D}$ sufficiency status ( $\mathrm{P}$ for trend $<0.001$ ). The adjusted hazard ratio (aHR) for the time to first event of asthma or recurrent wheeze obtained using Weibull regression model was 0.70 (95\%CI: 0.50-0.98, P=0.041) for cord blood vitamin D sufficiency not proceeded by maternal vitamin D sufficiency throughout pregnancy as compared to cord blood insufficiency. The hazard rate was lower if the cord blood sufficiency was preceded with maternal prenatal vitamin D sufficiency $(\mathrm{aHR}=0.51,95 \% \mathrm{CI}: 0.29-0.88 ; \mathrm{P}=0.02)$. 
Table 1.

Study Characteristics ( $\mathrm{N}_{\text {Total }}=806$ mother-child pairs).

\begin{tabular}{|c|c|c|}
\hline Features & Maternal Asthma(N=322) & No Maternal Asthma(N=484) \\
\hline $\begin{array}{l}\text { Asthma control status (N, \%) } \\
\text { Uncontrolled (at least one ACT score } \unlhd 6 \text { ) } \\
\text { Controlled } \\
\text { Missing }\end{array}$ & $\begin{array}{l}94(28.75) \\
227(70.94) \\
1\end{array}$ & -------- \\
\hline $\begin{array}{l}\text { Maternal monthly visits during pregnancy }(\mathrm{N}) \\
\text { Median } \\
\text { Range }\end{array}$ & $\begin{array}{c}5 \\
1-7\end{array}$ & $\begin{array}{c}5 \\
1-7\end{array}$ \\
\hline $\begin{array}{l}\text { Gestational age at enrollment (weeks) } \\
\text { Mean (SD) } \\
\text { Range }\end{array}$ & $\begin{array}{l}14.2(2.78) \\
9.86-18.71\end{array}$ & $\begin{array}{c}14.13(2.75) \\
2.10-19.0\end{array}$ \\
\hline $\begin{array}{l}\text { Maternal Age (years) } \\
\text { Mean (SD) } \\
\text { Range } \\
95 \% \text { central range } b\end{array}$ & $\begin{array}{l}26.7(5.40) \\
18.0-38.80 \\
18.70-35.30\end{array}$ & $\begin{array}{c}27.8(5.5) \\
18.0-39.52 \\
19.0-36.60\end{array}$ \\
\hline $\begin{array}{l}\text { Time from enrollment to delivery (weeks) } \\
\text { Mean (SD) } \\
\text { Range } \\
95 \% \text { central range }\end{array}$ & $\begin{array}{c}24.84(3.43) \\
11.14-31 \\
19.15-29.70\end{array}$ & $\begin{array}{l}24.85(3.43) \\
13.60-35.3 \\
19.6-29.60\end{array}$ \\
\hline $\begin{array}{l}\text { Gestational age at delivery (weeks) } \\
\text { Mean (SD) } \\
\text { Range } \\
95 \% \text { central range } \\
237 \text { weeks (N, \%) } \\
<37 \text { weeks (N, \%) }\end{array}$ & $\begin{array}{l}38.8(1.8) \\
26.0-42.10 \\
36.20-41.0 \\
295(91.61) \\
27(8.39)\end{array}$ & $\begin{array}{l}38.9(2.1) \\
26.20-42.30 \\
36.0-41.10 \\
438(90.87) \\
44(9.13)\end{array}$ \\
\hline $\begin{array}{l}\text { 25OHD levels (ng/mL) } \\
\text { Cord blood at delivery } \\
\text { Mean (SD) } \\
\text { Range } \\
95 \% \text { central range } \\
\text { N missing } \\
\text { Sufficiency status }(\mathrm{N}, \%) \\
<30(\mathrm{ng} / \mathrm{ml}) \\
330(\mathrm{ng} / \mathrm{ml}) \\
\mathrm{N} \text { missing } \\
\text { 32-38 weeks of gestation (maternal level) } \\
\text { Mean (SD) } \\
\text { Range } \\
95 \% \text { central range } \\
\mathrm{N} \text { missing } \\
\text { Sufficiency status }(\mathrm{N}, \%) \\
<30 \text { (ng/ml) } \\
230(\mathrm{ng} / \mathrm{ml}) \\
10-18 \text { weeks of gestation (maternal level) } \\
\text { Mean (SD) } \\
\text { Range } \\
95 \% \text { central range } \\
\text { N missing } \\
\text { Sufficiency status (N, \%) } \\
<30(\text { ng/ml) } \\
\geq 30 \text { (ng/ml) }\end{array}$ & $\begin{array}{c}37.10(17.4) \\
4.10-93.90 \\
12.62-67.22 \\
69(21.71) \\
91(27.83) \\
162(49.85) \\
69 \\
33.3(15.12) \\
5.8-81.3 \\
9.6-60.1 \\
16 \\
131(40.68) \\
175(54.35) \\
22.64(10.33) \\
4.35-65.30 \\
7.6-42.40 \\
2 \\
250(77.6) \\
70(21.71)\end{array}$ & $\begin{array}{c}37.0(18.8) \\
6.10-149 \\
11.62-71.64 \\
121(24.95) \\
139(28.43) \\
224(46.22) \\
121 \\
32.85(14.2) \\
5.7-90.10 \\
13.0-58.70 \\
20 \\
217(44.83) \\
247(51.03) \\
23.18(10.18) \\
4.5-80.80 \\
8.30-39.60 \\
3 \\
375(77.70) \\
106(21.70)\end{array}$ \\
\hline $\begin{array}{l}\text { Maternal eczema }(\mathrm{N}, \%) \\
\text { Yes } \\
\text { No }\end{array}$ & $\begin{array}{l}108(33.54) \\
214(66.46)\end{array}$ & $\begin{array}{l}149(30.79) \\
335(69.21)\end{array}$ \\
\hline $\begin{array}{l}\text { Maternal Allergic rhinitis }(\mathrm{N}, \%)^{*} \\
\text { Yes } \\
\text { No }\end{array}$ & $\begin{array}{l}227(70.50) \\
95(29.50)\end{array}$ & $\begin{array}{l}289(59.71) \\
195(40.29)\end{array}$ \\
\hline $\begin{array}{l}\text { Partner's allergic rhinitis }(\mathrm{N}, \%)^{*} \\
\text { Yes } \\
\text { No }\end{array}$ & $\begin{array}{l}96(29.81) \\
225(69.88) \\
1(0.31)\end{array}$ & $\begin{array}{l}248(51.24) \\
235(48.55) \\
1(0.21)\end{array}$ \\
\hline
\end{tabular}




\begin{tabular}{|c|c|c|}
\hline Features & Maternal Asthma(N=322) & No Maternal Asthma(N=484) \\
\hline \multicolumn{3}{|l|}{ Unknown } \\
\hline $\begin{array}{l}\text { Paternal asthma }(\mathrm{N}, \%)^{*} \\
\text { Yes } \\
\text { No } \\
\text { Unknown }\end{array}$ & $\begin{array}{c}57(17.70) \\
264(81.99) \\
1(0.31)\end{array}$ & $\begin{array}{c}130(26.86) \\
354(73.14) \\
0\end{array}$ \\
\hline $\begin{array}{l}\text { Paternal eczema }(\mathrm{N}, \%) \\
\text { Yes } \\
\text { No } \\
\text { Unknown }\end{array}$ & $\begin{array}{l}47(14.60) \\
274(85.09) \\
1(0.31)\end{array}$ & $\begin{array}{c}86(17.77) \\
396(81.82) \\
2(0.41)\end{array}$ \\
\hline $\begin{array}{l}\text { Number of pregnancies } \\
\text { Median } \\
\text { Range } \\
95 \% \text { central range } \\
\text { Category status (N, \%) } \\
\text { 1st } \\
>1\end{array}$ & $\begin{array}{c}2 \\
1-11 \\
1-6 \\
105(32.61) \\
217(67.39)\end{array}$ & $\begin{array}{c}2 \\
1-13 \\
1-5 \\
176(36.36) \\
306(63.74)\end{array}$ \\
\hline $\begin{array}{l}\text { Clinical center }(\mathrm{N}, \%) \\
\text { Boston } \\
\text { San Diego } \\
\text { St. Louis }\end{array}$ & $\begin{array}{l}93(28.88) \\
112(34.78) \\
117(36.34)\end{array}$ & $\begin{array}{l}147(30.37) \\
162(33.47) \\
175(36.16)\end{array}$ \\
\hline $\begin{array}{l}\text { Trial arm }(\mathrm{N}, \%) \\
\quad \text { Vitamin D intervention } \\
\text { Control }\end{array}$ & $\begin{array}{l}171(53.10) \\
151(46.90)\end{array}$ & $\begin{array}{l}234(48.35) \\
250(51.65)\end{array}$ \\
\hline $\begin{array}{l}\text { Gestational diabetes }(\mathrm{N}, \%) \\
\text { Yes } \\
\text { No }\end{array}$ & $\begin{array}{c}19(5.90) \\
302(94.1)\end{array}$ & $\begin{array}{c}28(5.90) \\
454(94.1)\end{array}$ \\
\hline $\begin{array}{l}\text { Body mass index at first appointment }\left(\mathrm{kg} / \mathrm{m}^{2}\right)^{*} \\
<25 \\
\geq 25 \\
\mathrm{~N} \text { missing }\end{array}$ & $\begin{array}{l}98(30.43) \\
208(65.6) \\
16(3.97)\end{array}$ & $\begin{array}{l}179(36.98) \\
278(57.43) \\
27(5.59)\end{array}$ \\
\hline $\begin{array}{l}\text { Race }(\mathrm{N}, \%) \\
\text { African American } \\
\text { Non-African American } \\
\text { White } \\
\text { American Indian or Alaska } \\
\text { Asian } \\
\text { Native Hawaiian } \\
\text { Other }\end{array}$ & $\begin{array}{l}147(45.65) \\
175(54.35) \\
125(38.82) \\
5(1.60) \\
9(2.80) \\
4(1.24) \\
32(9.89)\end{array}$ & $\begin{array}{l}200(41.32) \\
284(58.68) \\
201(41.53) \\
5(1.0) \\
27(5.58) \\
7(1.45) \\
44(9.12)\end{array}$ \\
\hline $\begin{array}{l}\text { Maternal marital status (N, \%) } \\
\text { Not Married/Divorced } \\
\text { Married }\end{array}$ & $\begin{array}{l}187(58.07) \\
135(41.93)\end{array}$ & $\begin{array}{l}252(52.07) \\
232(47.93)\end{array}$ \\
\hline $\begin{array}{l}\text { Maternal education completed (N, \%) } \\
\text { Less than college } \\
\text { less than high school } \\
\text { high school, technical school } \\
\text { some college } \\
\text { Above college } \\
\text { college graduate /graduate school }\end{array}$ & $\begin{array}{l}226(70.19) \\
47(14.60) \\
97(30.12) \\
82(25.47) \\
96(29.81)\end{array}$ & $\begin{array}{l}307(63.43) \\
53(10.95) \\
144(29.75) \\
110(22.73) \\
177(36.57)\end{array}$ \\
\hline $\begin{array}{l}\text { Child Sex } \\
\text { Male } \\
\text { Female } \\
\end{array}$ & $\begin{array}{l}178(54.28) \\
144(44.72)\end{array}$ & $\begin{array}{l}243(50.20) \\
241(49.80)\end{array}$ \\
\hline $\begin{array}{l}\text { Child's lower respiratory tract infection } \\
\text { Yes (at least one occasion) } \\
\text { No }\end{array}$ & $\begin{array}{l}116(36.02) \\
206(63.98)\end{array}$ & $\begin{array}{l}150(31) \\
334(69)\end{array}$ \\
\hline $\begin{array}{l}\text { Report of child's breast feeding before age of } 3 \mathrm{yrs} \\
\text { Yes } \\
\text { No } \\
\text { Missing }\end{array}$ & $\begin{array}{l}226(70.19) \\
61(18.94) \\
35(10.87)\end{array}$ & $\begin{array}{l}353(72.93) \\
89(18.39) \\
42(8.68)\end{array}$ \\
\hline
\end{tabular}

${ }^{a}$ Standard deviation. 
$b_{\text {Within the } 2.5^{\text {th }}}$ and $97.5^{\text {th }}$ percentiles of values.

* All P values of pairwise comparisons between characteristics of subjects with and without history of asthma diagnosis $>.05$ with the exception of body mass index at cutoff of $25 \mathrm{mg} / \mathrm{kg}^{2}$ at first appointment, partner with asthma, maternal allergic rhinitis, partner with allergic rhinitis $(\mathrm{P}<.05)$.

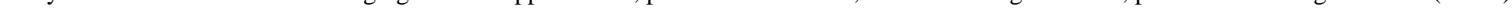


Table 2.

Risk of asthma or recurrent wheeze (asthma/recurrent wheeze) in the offspring's first three years of life by parental asthma diagnosis, maternal asthma and maternal asthma control status in Vitamin D Antenatal Asthma Reduction Trial (VDAART) adjusted for potential confounders using stepwise regression models

\begin{tabular}{|c|c|c|c|c|c|c|c|c|c|}
\hline \multirow[b]{2}{*}{ Variable } & \multicolumn{3}{|c|}{ Univariable analysis } & \multicolumn{3}{|c|}{$\begin{array}{l}\text { Multivariable analysis Main } \\
\text { variable: maternal and paternal } \\
\text { asthma diagnosis status }\end{array}$} & \multicolumn{3}{|c|}{$\begin{array}{l}\text { Multivariable analysis Main } \\
\text { variable: maternal asthma and } \\
\text { control status }\end{array}$} \\
\hline & $\mathrm{HR}$ & $95 \% \mathrm{CI}$ & P-value & Adjusted HR & $95 \% \mathrm{CI}$ & $\mathrm{P}$-value & Adjusted HR & $95 \% \mathrm{CI}$ & $\mathrm{P}$-value \\
\hline $\begin{array}{l}\text { Parental asthma } \\
\text { diagnosis } \\
\text { Both non- } \\
\text { asthmatics } \\
\text { Paternal asthma but } \\
\text { no maternal asthma } \\
\text { Maternal asthma } \\
\text { but no paternal asthma } \\
\text { Both asthmatics }\end{array}$ & $\begin{array}{c}1 \text { (Ref) } \\
1.03 \\
1.84 \\
1.95\end{array}$ & $\begin{array}{l}0.67-1.59 \\
1.36-2.49 \\
1.20-3.16\end{array}$ & $\begin{array}{c}0.90 \\
<0.001 \\
0.008\end{array}$ & $\begin{array}{c}1 \text { (Ref) } \\
0.90 \\
1.70 \\
2.30\end{array}$ & $\begin{array}{l}0.51-149 \\
1.17-2.40 \\
1.35-3.84\end{array}$ & $\begin{array}{l}0.62 \\
0.006 \\
0.003\end{array}$ & Not included & ----- & ----- \\
\hline $\begin{array}{l}\text { Maternal asthma } \\
\text { status } \\
\text { Non-asthmatics } \\
\text { Asthmatics with } \\
\text { controlled asthma } \\
\text { Asthmatics with } \\
\text { uncontrolled asthma } \\
\text { (at least one episode } \\
\text { during pregnancy) }\end{array}$ & $\begin{array}{l}1(\text { Ref }) \\
1.55 \\
2.80\end{array}$ & $\begin{array}{c}1.14-2.1 \\
1.98-3.99\end{array}$ & $\begin{array}{l}<0.001 \\
<0.001\end{array}$ & Not included & ----- & ----- & $\begin{array}{c}1 \text { (Ref) } \\
1.70 \\
2.40\end{array}$ & $\begin{array}{l}-\overline{---} \\
1.17-2.40 \\
1.50-3.50\end{array}$ & $\begin{array}{c}0---- \\
0.005 \\
<0.001\end{array}$ \\
\hline Maternal age & 0.95 & $0.93-0.97$ & $<0.001$ & ---- & ----- & ----- & ------ & ------ & ------ \\
\hline $\begin{array}{l}\text { Gestational age at } \\
\text { delivery } 237 \text { weeks vs } \\
<37 \text { weeks }\end{array}$ & 0.41 & $0.29-0.59$ & $<0.001$ & 0.43 & $0.26-0.71$ & 0.002 & 0.44 & $0.26-0.73$ & 0.002 \\
\hline $\begin{array}{l}\text { Trial arm Placebo vs } \\
\text { vitamin D intervention }\end{array}$ & 1.31 & $1.00-1.71$ & 0.0515 & & & & $-\bar{c}^{---}$ & $-\bar{c}^{---}$ & ---- \\
\hline $\begin{array}{l}\text { Cord blood Vitamin } \\
\text { D (ng/mL) } \\
\text { Sufficient vs. } \\
\text { insufficient ( } 230 \text { vs } \\
<30)\end{array}$ & 0.61 & $0.44-0.83$ & 0.002 & 0.66 & $0.47-0.90$ & 0.012 & 0.67 & $0.49-0.92$ & 0.012 \\
\hline $\begin{array}{l}\text { Offspring Sex } \\
\text { Male vs. Female }\end{array}$ & 1.64 & $1.25-2.16$ & $<0.001$ & 1.72 & $1.24-2.40$ & 0.009 & 1.76 & $1.27-2.45$ & 0.001 \\
\hline $\begin{array}{l}\text { Clinical site } \\
\text { Boston } \\
\text { San Diego } \\
\text { St. Louis }\end{array}$ & $\begin{array}{l}1(\text { Ref }) \\
0.52 \\
0.98\end{array}$ & $\begin{array}{l}0.37-0.75 \\
0.72-1.33\end{array}$ & $\begin{array}{c}<0.001 \\
0.91\end{array}$ & ----- & ----- & ---- & ---- & ---- & ---- \\
\hline $\begin{array}{l}\text { Race } \\
\text { White } \\
\text { African American } \\
\text { Other }\end{array}$ & $\begin{array}{l}1(\text { Ref }) \\
1.59 \\
0.82\end{array}$ & $\begin{array}{l}1.19-2.13 \\
0.53-1.29\end{array}$ & $\begin{array}{c}0.002 \\
0.39\end{array}$ & ----- & ------ & ----- & ----- & ----- & ----- \\
\hline $\begin{array}{l}\text { Maternal marital } \\
\text { status } \\
\quad \text { Married vs. } \\
\text { Unmarried or } \\
\text { Divorced) }\end{array}$ & 0.54 & $0.40-0.71$ & $<0.001$ & 0.60 & $0.40-0.82$ & 0.002 & 0.62 & $0.44-0.87$ & 0.006 \\
\hline $\begin{array}{l}\text { Parity } \\
\quad 1 \text { vs } \geq 2\end{array}$ & 1.05 & $0.8-1.4$ & 0.72 & ---- & ---- & ---- & ----- & ----- & ----- \\
\hline $\begin{array}{l}\text { Maternal education } \\
\text { College and above } \\
\text { vs. less } \\
\text { than College }\end{array}$ & 0.64 & $0.47-0.86$ & 0.004 & ---- & ---- & ---- & ---- & ---- & ----- \\
\hline
\end{tabular}




\begin{tabular}{|c|c|c|c|c|c|c|c|c|c|c|}
\hline \multirow{3}{*}{ 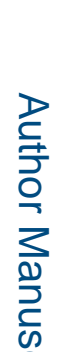 } & \multirow[b]{2}{*}{$\begin{array}{l}\text { Body mass index at } \\
\text { first appointment } \\
\text { BMI } \geq 25 \mathrm{vs} \text {. } \\
\text { BMI }<25 \mathrm{~kg} / \mathrm{m}^{2}\end{array}$} & \multicolumn{3}{|c|}{ Univariable analysis } & \multicolumn{3}{|c|}{$\begin{array}{l}\text { Multivariable analysis Main } \\
\text { variable: maternal and paternal } \\
\text { asthma diagnosis status }\end{array}$} & \multicolumn{3}{|c|}{$\begin{array}{l}\text { Multivariable analysis Main } \\
\text { variable: maternal asthma and } \\
\text { control status }\end{array}$} \\
\hline & & 1.13 & $0.84-1.5$ & 0.42 & ----- & ----- & ----- & ------ & ------ & ------ \\
\hline & $\begin{array}{l}\text { Maternal eczema } \\
\text { history } \\
\text { Yes vs. no }\end{array}$ & 1.10 & $0.83-1.46$ & 0.50 & ----- & ----- & ----- & ----- & ---- & ---- \\
\hline
\end{tabular}

Abbreviation: HR, hazard ratio. Hazard ratios for the outcome were estimated using a Weibull model; HRs and CIs are 2 sided. 
Table 3.

Multivariable model of the risk for offspring asthma/recurrent wheeze by age of 3 years, considering parental history of asthma diagnosis, maternal asthma and its control status and vitamin D status at 3 time points (enrollment, $3^{\text {rd }}$ trimester and cord blood at delivery)

\begin{tabular}{|c|c|c|c|c|c|c|c|}
\hline \multirow[b]{2}{*}{ Variable } & \multirow[b]{2}{*}{$\mathbf{N}$} & \multicolumn{3}{|c|}{ Multivariable Analysis $^{a}$} & \multicolumn{3}{|c|}{ Multivariable Analysis $^{a}$} \\
\hline & & Adjusted HR & $95 \% \mathrm{CI}^{b}$ & P-value & Adjusted HR & $95 \% \mathrm{CI}$ & P-value \\
\hline $\begin{array}{l}\text { Parental asthma diagnosis } \\
\text { Both non-asthmatics } \\
\text { Paternal asthma but no maternal asthma } \\
\text { Maternal asthma but no paternal asthma } \\
\text { Both asthmatics }\end{array}$ & $\begin{array}{c}355 \\
130 \\
264 \\
57\end{array}$ & $\begin{array}{c}1 \text { (Reference) } \\
0.90 \\
1.69 \\
2.30\end{array}$ & $\begin{array}{l}0.52-1.52 \\
1.18-2.41 \\
1.36-3.89\end{array}$ & $\begin{array}{l}0.66 \\
0.005 \\
0.002\end{array}$ & Not included & ---- & ---- \\
\hline $\begin{array}{l}\text { Maternal asthma status } \\
\text { Non-asthmatics } \\
\text { Asthmatics with controlled asthma } \\
\text { Asthmatics with uncontrolled asthma (at least } \\
\text { one episode during pregnancy) }\end{array}$ & $\begin{array}{l}484 \\
227 \\
94\end{array}$ & Not included & ---- & ---- & $\begin{array}{c}1 \text { (Reference) } \\
1.67 \\
2.32\end{array}$ & $\begin{array}{l}1.17-2.38 \\
1.52-3.55\end{array}$ & $\begin{array}{l}<0.001 \\
<0.001\end{array}$ \\
\hline $\begin{array}{l}\text { Vitamin D sufficiency status ( } \mathbf{3 0} \text { or }<\mathbf{3 0} \\
\text { ng/mL) } \\
\text { Cord blood insufficiency } \\
\text { Cord blood sufficiency and maternal } \\
\text { insufficiency at either } 32-38 \text { or } 10-18 \text { weeks of } \\
\text { gestation or both } \\
\text { Cord blood sufficiency and maternal } \\
\text { sufficiency at both } 32-38 \text { and } 10-18 \text { weeks of } \\
\text { gestation }\end{array}$ & $\begin{array}{l}230 \\
285 \\
101\end{array}$ & $\begin{array}{c}1 \text { (Reference) } \\
0.71 \\
0.47\end{array}$ & $\begin{array}{c}0.51-0.998 \\
0.27-0.83\end{array}$ & $\begin{array}{l}0.05 \\
0.01\end{array}$ & $\begin{array}{c}1 \text { (Reference) } \\
0.70 \\
0.51\end{array}$ & $\begin{array}{l}0.50-0.98 \\
0.29-0.88\end{array}$ & $\begin{array}{c}0.041 \\
0.02\end{array}$ \\
\hline
\end{tabular}

a. The hazard ratios (HR) are also adjusted for the confounders and covariates in the main analysis, including gestational age for delivery ( 237 weeks vs. <37 weeks), maternal marital status, trial arm, clinical center, race, parity, maternal education, obesity status at first appointment (BMI 25 ).

b. $\mathrm{CI}$ : Confidence Interval 